\title{
PENERAPAN METODE DEMONSTRASI DENGAN MENGGUNAKAN MEDIA AUDIO VISUAL UNTUK MENINGKATKAN PEMAHAMAN MENGENAI SISTEM TATA SURYA PADA SISWA KELAS VII SMP NEGERI 8 TEBING TINGGI
}

\author{
Arnot Pakpahan \\ Surel : arnotpakpahan20@gmail.com
}

\begin{abstract}
ABSTRAK
Pada pelaksanaan pembelajaran Ilmu Pengetahuan Alam tentang Tata Surya sebagian besar siswa memperoleh nilai di bawah standar ketuntasan belajar minimal yang sudah ditentukan pada siklus I, yaitu 60. Hal ini karena guru hanya memberikan metode ceramah tanpa menggunakan media, Hasil belajar yang dicapai siswa pada siklus II mengalami peningkatan dibandingkan pada siklus I yakni mencapai rata-rata 65. Metode dan Media yang digunakan lebih konkrit sehingga siswa menjadi terlihat lebih aktif. Hal ini berpengaruh pada hasil yang diperoleh untuk rata-rata kelas lebih meningkat dari siklus sebelumnya yaitu mencapai 74 . Hal ini menunjukkan bahwa pembelajaran sudah dapat dikatakan berhasil.
\end{abstract}

Kata Kunci: Demonstrasi, Media Audio Visual

\section{PENDAHULUAN}

Dalam lingkup mikro pendidikan diwujudkan melalui proses belajar mengajar di dalam kelas maupun di luar kelas. Proses ini berlangsung edukatif. Melalui proses belajar mengajar inilah peserta didik akan mengalami proses perkembangan kearah yang lebih baik dan bermakna agar hal tersebut dapat terwujud maka diperlukan suasana proses belajar mengajar yang kondusif bagi peserta didik dalam melampaui tahapan-tahapan belajar secara bermakna dan efektif sehingga menjadi pribadi yang percaya diri, inovatif dan kreatif (Surya, 1992: 179).

Untuk meningkatkan mutu pendidikan, pemerintah memperbaiki dan mengubah kurikulum yang digunakan di sekolah. Akan tetapi, apapun jenis dan nama kurikulum yang digunakan, keberhasilan pembelajaran di sekolah bergantung pada implementasinya dalam pembelajaran oleh guru. Guru merupakan faktor yang berpengaruh sangat besar dalam proses belajar mengajar, bahkan sangat menentukan keberhasilan siswa dalam belajar.

Pendidikan adalah proses memproduksi sistem nilai dan budaya ke arah yang lebih baik, antara lain dalam pembentukan kepribadian, keterampilan dan perkembangan intelektual siswa. Dalam lembaga formal proses reproduksi nilai dan budaya ini dilakukan terutama dengan mediasi proses belajar mengajar sejumlah mata pelajaran di kelas. Salah satu mata pelajaran yang turut berperan 
penting dalam pendidikan wawasan, keterampilan dan sikap ilmiah sejak dini bagi anak adalah mata pelajaran IPA. Ilmu Pengetahuan Alam adalah pengetahuan yang rasional dan objektif tentang alam semesta dan segala isinya. Usaha untuk meningkatkan pemahaman siswa memerlukan metode yang efektif dan efisien. Selain itu, diperlukan pula media pembelajaran yang tepat sehingga siswa dapat menguasai kompetensi yang diharapkan. Dalam proses belajar mengajar, media memiliki peran yang sangat penting menunjang tercapainya tujuan pembelajaran. Penerapan metode demonstrasi dengan menggunakan media audio visual dalam pembelajaran mengenai sistem tata surya diharapkan membangkitkan rasa ingin tahu dan minat siswa serta motivasi untuk belajar, juga dapat mempermudah siswa dalam memahami materi dan informasi yang disampaikan. Dengan demikian, penerapan metode demonstrasi dengan menggunakan media audio visual diharapkan dapat meningkatkan pemahaman mengenai tata surya pada siswa kelas VII.

Yang dimaksud dengan

Metode Demonstrasi ialah metode mengajar dengan menggunakan peragaan untuk memperjelas suatu pengertian atau untuk memperlihatkan bagaimana berjalannya atau bekerjanya suatu proses atau langkah-langkah kerja dari suatu alat atau instrumen tertentu kepada siswa. Hal-hal yang perlu diperhatikan dalam metode demonstrasi:

a. Demonstrasi akan menjadi metode yang tidak wajar apabila alat yang di Demonstrasikan tidak bisa di amati dengan seksama oleh siswa. misalnya alatnya terlalu kecil atau penjelasannya tidak jelas.

b. Demonstrasi menjadi kurang efektif bila tidak diikuti oleh aktivitas di mana siswa sendiri dapat ikut memperhatikan dan menjadi aktivitas mereka sebagai pengalaman yang berharga.

c. Tidak semua hal dapat didemonstrasikan di kelas karena alat-alat yang terlalu besar atau yang berada di tempat lain yang tempatnya jauh dari kelas.

d. Hendaknya dilakukan dalam halhal yang bersifat praktis tetapi dapat membangkitkan minat siswa.

e. Guru harus dapat memperagakan demonstrasi dengan sebaikbaiknya, karena itu guru perlu mengulang-ulang peragaan di rumah dan memeriksa semua alat yang akan dipakai sebelumnya sehingga sewaktu mendemonstrasikan di depan kelas semuanya berjalan dengan baik.

Aristo (2004: 13) menjelaskan secara umum dalam proses pembelajaran media memiliki fungsi yang sangat penting yaitu memperlancar interaksi antara siswa dan guru sehingga kegiatan pembelajaran akan lebih efektif dan efisien. Banyak batasan yang 
diberikan para ahli mengenai media. Asosiasi Teknologi dan Komunikasi Pendidikan (Association of Education and Communication Technology/AECT), membatasi media sebagai segala bentuk dan saluran yang digunakan orang untuk menyalurkan pesan atau informasi.

Sementara Gagne (1970) berpendapat bahwa media adalah berbagai jenis komponen dalam lingkungan siswa yang dapat merangsang siswa tersebut untuk belajar. Briggs (1970) menyatakan bahwa media adalah segala alat fisik yang dapat menyajikan pesan serta merangsang siswa untuk belajar.

Media audio visual merupakan salah satu media yang digunakan dalam pembelajaran menyimak. Media ini dapat menambah minat siswa dalam belajar karena siswa dapat menyimak sekaligus melihat gambar. Aristo (2004: 56) menjelaskan bahwa fungsi media pembelajaran, khususnya media audio visual bukan saja berfungsi menyalurkan pesan, melainkan membantu menyederhanakan proses penyampaian pesan yang sulit sehingga komunikasi dapat menjadi lancar. Dengan uraian di atas media audio visual sangat berguna dan membantu pencapaian tujuan pembelajaran. Asnawir (2002: 5758) menjelaskan bahwa media audio visual memiliki kesanggupan untuk; pertama menembus ruang dan waktu, kedua menerjemahkan pesan menjadi satuan esensial, ketiga memberikan pengalaman sosial dan emosional, keempat memberikan motivasi, kelima memperjelas pemahaman.

Pada pelaksanaan pembelajaran Ilmu Pengetahuan Alam tentang Tata Surya menunjukkan hasil belajar yang kurang memuaskan. Tata surya adalah matahari dan keluarga benda antariksa yang mengedarinya. Tata Surya terdiri dari sebuah bintang yang disebut Matahari (dalam sistem tatasurya kita) dan semua objek yang mengelilinginya. Dalam tata surya kita, objek yang mengelilingi matahari sebagai pusat tata surya itu adalah planet bersama satelitnya yang mengorbit secara elips, meteor, komet, asteroid, dan planet-planet kecil. Tata Surya terbagi menjadi Matahari, empat planet bagian dalam, sabuk asteroid, empat planet bagian luar, dan di bagian terluar adalah Sabuk Kuiper dan piringan tersebar. Awan Oort diperkirakan terletak di daerah terjauh yang berjarak sekitar seribu kali di luar bagian yang terluar.

Sebagian besar siswa memperoleh nilai di bawah standar ketuntasan belajar minimal yang sudah ditentukan. Selama proses pembelajaran berlangsung, sebagian besar siswa kurang bersemangat mengikutinya, dan ketika diberikan soal-soal latihan mereka mengalami kesulitan dalam mengerjakannya, hal ini terjadi karena para siswa belum memahami materi pelajaran yang telah dikelaskan oleh guru. Berdasarkan hal tersebut di atas, maka penulis mencoba untuk mengidentifikasi faktor penyebab kurang berhasilnya proses 
pembelajaran yang sudah dilaksanakan sehingga hasil belajar siswa rendah. Ada beberapa masalah yang terjadi dalam proses pembelajaran, yaitu :

a. Rendahnya tingkat penguasaan siswa terhadap materi pelajaran, hal ini dapat dilihat dari hasil tes yang masih di bawah standar KKM

b. Teknik pembelajaran mengenai sistem tata surya kurang bervariasi

c. Siswa kurang termotivasi untuk mengikuti pelajaran

Berdasarkan identifikasi masalah yang dikemukakan, penulis mencoba menganalisis penyebab rendahnya hasil belajar siswa, di antaranya: (1) Mengapa hasil belajar siswa rendah ? (2) Mengapa penguasaan materi pelajaran siswa dalam proses pembelajaran rendah ?

(3) Mengapa siswa kurang termotivasi dalam mengikuti pelajaran?

Berdasarkan analisis masalah di atas, maka yang akan menjadi fokus perbaikan pembelajaran adalah: "Apakah penerapan metode demonstrasi dengan menggunakan media audio visual dapat meningkatkan pemahaman mengenai sistem tata surya pada siswa kelas VII ?"

Berdasarkan pertanyaan penelitian tindakan kelas yang terdapat pada rumusan masalah di atas, maka penelitian ini bertujuan untuk meningkatkan pemahaman mengenai sistem tata surya pada siswa kelas VII melalui penerapan metode demonstrasi dengan menggunakan media audio visual.

\section{METODE PENELITIAN}

Penelitian ini dilaksanakan di SMP Negeri 8 Tebing Tinggi, yang berada di wilayah Kecamatan Rambutan Kota Tebing Tinggi. Penelitian ini terdiri dari 3 siklus, yang dilaksanakan selama bulan April 2016.

Prosedur perbaikan pembelajaran yang dilaksanakan mengacu kepada tahap Penelitian Tindakan Kelas (PTK). Pelaksanaan perbaikan pembelajaran dilaksanakan di kelas VII SMPN Negeri 8 Tebing Tinggi. Langkahlangkah yang ditempuh pada perbaikan pembelajaran yaitu, sebagai berikut:

Adapaun rencana perbaikan yang dilakukan oleh penulis adalah sebagai berikut: (1) Mengamati proses belajar mengajar di kelas, (2) Penulis mengumpulkan data berupa peristiwa dan hasil belajar yang dicapai oleh siswa, (3) Melakukan wawancara dengan siswa untuk mengetahui keinginan mereka untuk belajar, (4) Melakukan pemeriksaan kembali dokumen yang ada seperti rencana persiapan mengajar dan soal evaluasi. Berikut ini, guru melakukan pelaksanaan perbaikan, yaitu :

a. Guru memberikan materi pokok tentang matahari sebagai pusat tata surya.

b. Siswa memperhatikan penjelasan guru tentang matahari sebagai pusat tata surya. 
c. Siswa dan guru melakukan tanya jawab dan guru memberikan soal-soal latihan.

d. Siswa mengerjakan soal latihan.

e. Membahas soal latihan bersamasama.

f. Diakhir pembelajaran guru bersama siswa menyimpulkan materi pelajaran dan memberikan tindak lanjut berupa PR.

Hal-hal yang dapat dilakukan pada Siklus I dalam pengamatan yaitu :

a. Dalam proses belajar mengajar siswa kurang aktif dan masih ada yang bermain dengan temannya.

b. Anak masih ada yang tidak dapat menyelesaikan tugas tepat waktu.

c. Guru kurang memantau siswa saat mengerjakan latihan atau tugas yang diberikan.

Melakukan refleksi, yaitu :

a. Hasil evaluasi pada siklus ini dengan rata-rata masih kurang dari Kriteria Ketuntasan Minimal (KKM) yaitu 59 yang seharusnya 60.

b. Siswa yang banyak bermain di kelas dan mengganggu temannya diberi teguran oleh guru.

c. Masih adanya siswa yang tidak dapat menyelesaikan tugas karena belum tepatnya penggunaan metode pembelajaran.

$\begin{array}{llr}\text { Pada siklus II penulis } \\ \text { menyampaikan materi } & \text { tentang } \\ \text { palnet-planet dalam tata } & \text { surya. }\end{array}$

Peneliti melakukan rencana perbaikan, yaitu :

a. Pengkondisian siswa.

b. Menyiapkan alat peraga berupa gambar.

c. Menggunakan metode tanya jawab dan latihan.

d. Membuat soal evaluasi.

Yang harus diperhatikan dalam melakukan pelaksaan perbaikan :

a. Guru memberikan motivasi kepada siswa yang belum memahami materi pelajaran.

b. Memberikan penjelasan materi pelajaran tentang anggota tata surya.

c. Siswa diajak mengamati gambar anggota tata surya.

d. Siswa diminta menyebutkan anggota dari tata surya.

e. Memberikan kesempatan kepada siswa untuk bertanya pada guru.

f. Diakhir pembelajaran guru bersama siswa menyimpulkan materi pelajaran, memberikan tindak lanjut, memberikan tuga berupa PR serta menutup pelajaran.

Melakukan pengamatan dan pengumpulan data :

a. Memberikan penguatan kepada siswa yang dapat menyelesaikan tugas dan memberikan semangat bagi siswa yang belum menguasai materi pelajaran.

b. Menggunakan metode ceramah, tanya jawab dan pemberian tugas. 
Melakukan refleksi, yaitu :

a. Awal pembelajaran yang baik dapat meningkatkan semangat belajar.

b. Penggunaan media yang tepat dapat memudahkan pemahaman materi.

c. Mengadakan penelitian hasil sebagai perbandingan dari hasil sebelumnya dan sebagai bahan untuk penentu hasil berikutnya.

Pada siklus III ini penulis menekankan rencana perbaikan pembelajaran dengan metode demonstrasi dengan menggunakan media audio visual.

a. Pengkondisian siswa

b. Menyampaikan tujuan pembelajaran

c. Guru menyiapkan media audio visual berupa tayangan gambar tentang sifat dan keadaan 8 planet dalam tata surya

d. Mengadakan tanya jawab seputar materi yang akan di bahas.

e. Mengoreksi kembali dokumen yang ada seperti persiapan mengajar dan lembar evaluasi.

Yang harus diperhatikan dalam melakukan pelaksaan perbaikan :

a. Guru memberikan motivasi kepada siswa yang belum memahami materi pelajaran.

b. Memberikan penjelasan materi pelajaran tentang profil dari 8 planet dalam tata surya.

c. Siswa diajak mengamati tayangan gambar melalui media LCD yang menunjukkan sifat dan keadaan 8 planet dalam tata surya.

d. Siswa diberi pertanyaanpertanyaan sesuai dengan isi tayangan gambar dengan tujuan agar siswa lebih mengerti tentang materi yang dipelajari.

e. Siswa diberi tes yang sudah dipersiapkan dengan tujuan untuk mengetahui sejauh mana penguasannya terhadap materi yang sudah dipelajari.

f. Di akhir pembelajaran guru bersama siswa menyimpulkan materi pelajaran, memberikan tindak lanjut, serta menutup pelajaran.

Melakukan pengamatan dan pengumpulan data :

a. Penggunaan media audio visual sesuai dengan rencana pembelajaran.

b. Menggunakan metode demonstrasi sehingga membuat siswa belajar lebih menyenangkan.

Melakukan refleksi, yaitu :

a. Awal pembelajaran yang baik dapat meningkatkan semangat belajar.

b. Penggunaan media yang tepat dapat membuat siswa lebih antusias dalam belajar.

c. Dengan penggunaan metode demonstrasi melalui media audio visual dapat menigkatkan prestasi dan penguasaan siswa terhadap materi yang dipelajari. 
HASIL PENELITIAN DAN PEMBAHASAN

Peneltian ini dilakukan pada 3 siklus dalam mata pelajaran Ilmu Pengetahuan Alam (IPA) tentang Sistem Tata Surya. Waktu yang digunakan untuk setiap kali pertemuan adalah 70 menit. Berdasarkan hasil penelitian yang dilakukan dari pembelajaran siklus pertama hingga yang ketiga menunjukkan adanya perubahan baik pada diri siswa, hasil belajar maupun kemampuan profesionalisme gurunya.

Dari data pada siklus I menunjukkan bahwa walaupun hasil rata-rata kelas mencapai nilai 60 ternyata masih ada siswa yang belum tuntas karena mendapatkan nilai di bawah KKM. Siswa yang mendapat nilai 100 dan 90 tidak ada, siswa yang mendapat nilai 80 hanya 6 orang $(18,67 \%)$, siswa yang mendapat nilai 70 sebanyak 11 orang $(29,96 \%)$, siswa yang mendapatkan nilai 60 sebanyak 9 orang $(21 \%)$, siswa yang mendapatkan nilai 50 sebanyak 12 orang $(23,34 \%)$, siswa yang mendapatkan nilai 40 sebanyak 3 orang $(4,67 \%)$, siswa yang mendapatkan nilai 30 sebanyak 2 orang $(2,33 \%)$. Berdasarkan hasil yang dicapai tersebut maka siswa yang mencapai ketuntasan belajar sebanyak 17 orang yaitu sekitar $49 \%$. Sedangkan yang tidak mencapai ketuntasan belajar sebanyak 26 orang yaitu sekitar $51 \%$.

Dari data pada siklus II menunjukkan adanya peningkatan yang semula rata-rata kelas mencapai nilai 60 tetapi pada siklus II rataratanya mencapai 65 . Hasil tes pada siklus II siswa yang mendapat nilai 100 tidak ada, siswa yang mendapat nilai 90 berjumlah 1 orang $(3,21 \%)$, siswa yang mendapat nilai 80 sebanyak 9 orang $(25,71 \%)$, siswa yang mendapatkan nilai 70 sebanyak 13 orang $(32,50 \%)$, siswa yang mendapatkan nilai 60 sebanyak 10 orang $(21,43 \%)$, siswa yang mendapatkan nilai 50 sebanyak 8 orang (14,29\%), siswa yang mendapatkan nilai 40 sebanyak 2 orang $(2,86 \%)$. Berdasarkan hasil yang dicapai tersebut maka siswa yang mencapai ketuntasan sebanyak 23 orang yaitu sekitar $61 \%$. Sedangkan, yang tidak mencapai ketuntasan belajar sebanyak 20 orang yaitu sekitar 39\%.

Dari data pada siklus III menunjukkan kenaikan yang cukup siginifikan yaitu hasil rata-rata kelas mencapai nilai $73 \%$ dimana Siswa yang mendapat nilai 100 sebanyak 3 orang $(9,29 \%)$, siswa yang mendapat nilai 90 sebanyak 5 orang $(14,24 \%)$, siswa yang mendapat nilai 80 sebanyak 12 orang $(30,38 \%)$, siswa yang mendapatkan nilai 70 sebanyak 12 orang (26,58\%), siswa yang mendapatkan nilai 60 sebanyak 6 orang $(11,40 \%)$, siswa yang mendapatkan nilai 50 sebanyak 5 orang $(7,91 \%)$. Dari data nilai siklus III dapat ditarik kesimpulan bahwa proses perbaikan pelajaran IPA dengan materi tentang sistem tata surya ini sudah dapat dikatakan berhasil dan mencapai Kriteria Ketuntasan Minimal (KKM) yaitu 32 
orang (81\%). Jadi proses pembelajaran ini sudah tidak perlu diadakan perbaikan lagi.

Berdasarkan observasi dan hasil diskusi dengan teman sejawat, diperoleh hasil bahwa perlu diadakannya perbaikan pembelajaran di setiap siklus. Setelah melaksanakan proses pembelajaran tiga siklus untuk materi tentang sistem tata surya maka terdapat temuan sebagai berikut:

a. Selama pelajaran pada siklus 1 peneliti tidak menggunakan hanya menggunakan metode ceramah dan tanya jawab. Dengan cara belajar tersebut siswa didik menjadi lebih cepat bosan dan hasil yang diperoleh juga tidak begitu baik. Hal ini dapat dilihat dari hasil nilai ulangan siklus 1 , dimana nilai rata - ratanya 60 dengan 26 dari 43 siswa mendapat nilai dibawah 65. Sedangkan, pada siklus II dimana peneliti menggunakan media peraga, para siswa menjadi lebih aktif dalam proses pembelajaran dan juga memahami materi pelajaran yang diajarkan. Hal ini mempengaruhi hasil nilai ulangan pada siklus II ini, dimana nilai rata - rata siswa lebih meningkat menjadi 65 dan terdapat 20 dari 43 siswa yang mendapat nilai dibawah 65 .

b. Apabila diperhatikan perubahan yang terjadi pada nilai siswa pada siklus I dan II menunjukan hal yang positif. Namun hasil yang diperoleh peneliti dinilai masih kurang memuaskan. Oleh karena itu peneliti mengadakan siklus III dengan memperbaiki strategi dalam proses pembelajaran. Pada siklus III ini peneliti menerapkan metode demonstrasi dengan menggunakan media audio visual dalam proses pembelajaran.

c. Dengan menggunakan strategi pembelajaran yang baik dan metode pmebelajaran yang bervariatif serta media audio visual siswa menjadi lebih aktif dan menguasai materi pembelajaran lebih bagus bila dibandingkan dengan siklus sebelumnya. Hal ini terlihat dari hasil nilai ulangan yang diperoleh siswa pada siklus III ini, dimana rata - rata yang didapat dalah 74 dan hanya 11 orang siswa yang mendapat nilai kurang dari 64.

\section{Pembahasan}

Selama proses pembelajarn, aktifitas guru kurang menarik minat dan perhatian siswa. Dengan metode ceramah guru terlalu banyak memberikan penjelasan tanpa memberikan menggunakan media peraga apapun, guru kurang memberikan kesempatan kepada siswa untuk terlibat dalam proses pembelajaran akibatnya proses pembelajaran kurang berhasil. Siswa hanya diam mendengarkan penjelasan guru. Aktifitas dan kreatifitas siswa kurang terpacu, siswa kurang terlibat dalam proses pembelajaran dan kurang diberi latihan. Hasil belajar siswa pada siklus I mata pelajaran IPA rendah, 
yaitu 60, hal ini karena guru hanya memberikan metode ceramah tanpa menggunakan media yang dapat menarik perhatian siswa.

Hasil pembelajaran pada siklus II ditunjukkan sebagai berikut: Proses kegiatan belajar mulai menarik perhatian siswa serta terlihat semangat dan aktif dalam mendemonstrasikan alat peraga yang disiapkan oleh guru. Penggunaan media penunjang berupa gambar ternyata mulai menarik perhatian siswa. Siswa mulai aktif menjawab pertanyaaan-pertanyaan yang diajukan guru. Hasil belajar yang dicapai siswa pada siklus II mengalami peningkatan dibandingkan pada siklus I yakni mencapai rata-rata 65 .

Hasil pembelajaran pada siklus III ditunjukkan sebagai berikut:

a. Proses kegiatan belajar mengajar berbeda dengan siklus I dan II. Guru tidak hanya menerangkan dengan menggunakan metode ceramah, tetapi juga dengan menerapkan metode demonstrasi dengan menggunakan media audio visual. Siswa diberi latihan-latihan dan dalam mendemonstrasikan alat peraga difokuskan pada anak yang daya serapnya rendah, tujuannya agar meningkatkan daya ingatnya.

b. Metode dan Media yang digunakan lebih konkrit sehingga siswa menjadi terlihat lebih aktif. Guru hanya memancing siswa dengan beragam pertanyaan sesuai gambar yang disajikan dengan menggunakan media audio visual, sehingga siswa termotivasi untuk mengutarakan pendapatnya dan memudahkan bagi siswa untuk memahami materi tentang sistem tata surya. Hal ini berpengaruh pada hasil yang diperoleh untuk rata-rata kelas lebih meningkat dari siklus sebelumnya yaitu mencapai 74 . Dengan demikian kegiatan perbaikan ini sesuai dengan rencana. Hal ini menunjukkan bahwa pembelajaran sudah dapat dikatakan berhasil.

\section{SIMPULAN}

Setelah melakukan Penelitian Tindakan Kelas (PTK) yaitu tiga siklus untuk materi tentang sistem tata surya dapat ditarik kesimpulan sebagai berikut :

a. Penggunaan metode dan media pembelajaran secara tepat mampu memicu keterlibatan siswa secara maksimal dalam proses pembelajaran sehingga dapat memotivasi siswa dalam meningkatkan hasil belajarnya.

b. Sebagai motivator dan fasilitator, guru harus dapat menciptakan kondisi agar siswa tertarik untuk belajar, kondisi ini dapat diciptakan jika guru mampu menggunakan metode dan media belajar yang efektif pada pembelajaran tentang sistem tata surya secara tepat. 


\section{DAFTAR RUJUKAN}

Arikunto, dkk. 2007. Penelitian Tindakan Kelas. Jakarta: Bumi Aksara.

Djamarah, dkk. 2007. Stategi Belajar Mengajar. Jakarta: PT Rineka Cipta.

Hamalik. 2010. Kurikulum dan Pembelajaran. Jakarta: Bumi Aksara.

Sanjaya, W. 2010. Strategi Pembelajaran Berorientasi
Standar Proses Pendidikan. Jakarta : Kencana.

Slameto. 2010. Belajar dan FaktorFaktor Yang Mempengaruhinya. Jakarta: Rineka Cipta.

Sudjana, N. 2009. Penilaian Hasil Proses Belajar Mengajar. Bandung: PT Remaja Rosdakarya. 